\title{
Inflammatory Response to Cobalt-Chromium Alloys Fabricated With Different Techniques
}

\author{
Maria Kassapidou ${ }^{1,2}$, Victoria Franke Stenport ${ }^{1}$, Carina B. Johansson ${ }^{1}$, Anna-Karin Östberg ${ }^{3}$, \\ Petra Hammarström Johansson ${ }^{1}$, Lars Hjalmarsson ${ }^{1,4}$ \\ ${ }^{1}$ Department of Prosthodontics/Dental Materials Science, Institute of Odontology, The Sahlgrenska Academy, University of \\ Gothenburg, Box 450, SE 40530 Göteborg, Sweden. \\ ${ }^{2}$ Department of Prosthetic Dentistry, Institute for Postgraduate Dental Education, Jönköping, and Department of Biomedical \\ and Clinical Sciences, Linköping University, Linköping, Sweden. \\ ${ }^{3}$ Department of Oral Microbiology and Immunology, Institute of Odontology, The Sahlgrenska Academy, University of \\ Gothenburg, Göteborg, Sweden. \\ ${ }^{4}$ Dental Clinic, Folktandvården Sörmland AB, The Mälar Hospital, SE-631 88 Eskilstuna, Sweden and Centre for Clinical \\ Research Sörmland, Uppsala University, Eskilstuna, Sweden.
}

\section{Corresponding Author:}

Maria Kassapidou

Department of Prosthodontics/Dental Materials Science, Institute of Odontology

The Sahlgrenska Academy, University of Gothenburg

Box 450, SE 40530 Göteborg

Sweden

Phone: +46-31-786 0000

E-mail: maria.kassapidou@gu.se

\section{ABSTRACT}

Objectives: To explore the in vitro cytokine expression of human peripheral blood mononuclear cells exposed to cobaltchromium alloys, manufactured with different techniques, in comparison with commercially pure titanium grade 4 and titanium alloy grade 23 .

Material and Methods: Peripheral blood mononuclear cells (PBMC) were collected from 10 healthy blood donors and exposed to machine-ground coin-shaped: (a) cobalt-chromium $(\mathrm{Co}-\mathrm{Cr})$ specimens $(\mathrm{n}=5)$ manufactured by four techniques, i.e. cast, milled, laser melted and presintered milled; (b) commercially pure titanium grade 4; and (c) titanium alloy grade 23. The cells were cultured for 4, 24 and 72 hours followed by investigations of pro- and anti-inflammatory cytokine release using Bio-Plex Pro ${ }^{\mathrm{TM}}$.

Results: In general, the PBMC produced significantly more cytokines when exposed to the cast and presintered milled Co-Cr materials compared to laser melted, milled $\mathrm{Co}-\mathrm{Cr}$ and titanium materials.

Conclusions: Within the limitation of the present study, it may be suggested that cast and presintered milled cobalt-chromium alloys provoke a stronger inflammatory response compared to milled and laser melted cobalt-chromium alloys and titanium materials.

Keywords: cobalt-chromium alloys; cytokine; dental casting technique; inflammation; prosthodontics; titanium.

Accepted for publication: 29 December 2021

To cite this article:

Kassapidou M, Stenport VF, Johansson CB, Östberg AK, Hammarström Johansson P, Hjalmarsson L.

Inflammatory Response to Cobalt-Chromium Alloys Fabricated With Different Techniques

J Oral Maxillofac Res 2021;12(4):e3

URL: http://www.ejomr.org/JOMR/archives/2021/4/e3/v12n4e3.pdf

doi: $10.5037 /$ jomr.2021.12403 


\section{INTRODUCTION}

Cobalt-chromium (Co-Cr) alloys are being used in the rehabilitation of partially dentate and edentulous patients. In a publication from 2017 it was reported that more than 30 different $\mathrm{Co}-\mathrm{Cr}$ alloys were used in Sweden for this purpose [1]. Except for variations in composition among the used alloys, they are also manufactured by different techniques, i.e. cast, milled, laser melted and presintered milled [1].

A recent in vitro study investigating the ion release from four different $\mathrm{Co}-\mathrm{Cr}$ alloys demonstrated a higher ion release from cast and presintered milled $\mathrm{Co}-\mathrm{Cr}$ as compared to milled and laser melted alloys [2]. Furthermore, a higher cell viability to cast Co$\mathrm{Cr}$ compared to titanium alloy grade 23 (Ti-6Al$4 \mathrm{~V}$ ELI [extra low interstitial]) was reported [2] It has been discussed that ion release may initiate an inflammatory response that further activates the host's immune system [픈 $\underline{4}$. The inflammatory response initiates the infiltration of neutrophils and later monocytes and lymphotic cells in the affected area [4]. It has been suggested that an activated inflammatory response may lead to tissue destruction around the implant [5]. In vitro studies have demonstrated that titanium (Ti) ions form particles which have been associated with the stimulation of macrophages that release interleukins (IL)- $1 \beta$, known for their involvement in bone resorption [6]. In the orthopaedic field, it has been shown that cobalt $(\mathrm{Co})$ ions and particles that are released from orthopaedic implants can be absorbed by macrophages which induce a type IV hypersensitivity reaction $[\underline{7}, \underline{8}]$. Both T-lymphocytes and B-cells (to a lesser extent) are involved in the production of inflammatory mediators, such as cytokines, that regulate the inflammatory phase [9]. Pro- and antiinflammatory cytokines, i.e. the interleukins IL-1, IL-6, IL-4 and tumour necrosis factor- $\alpha$ (TNF- $\alpha$ ), play a central role in the inflammatory reaction $[10,11]$. The complex interplay between pro- and anti-inflammatory cytokines in an inflammatory process is not fully understood [11]. While the proinflammatory cytokines usually act as the dominating mediators for the inflammatory response, the antiinflammatory cytokines inhibit their release and may cause a weakened inflammatory response [11]. When the phagocytosis of the macrophages fails to eliminate the ions, the macrophages release cytokines, i.e. IL-1, IL- 6 , TNF- $\alpha$ and prostaglandin [7]. The pro-inflammatory cytokines IL-1 ( $\mathrm{r} \alpha$ and $\beta$ ) and TNF- $\alpha$ have also been shown to stimulate bone resorption and are generally classified as key pro-inflammatory proteins $[7,12,13]$. In two other in vitro studies, high levels of proinflammatory cytokine release (IL-1 $\beta$, IL- 6 , IL-8 and TNF- $\alpha$ ) were demonstrated when human monocyte cell lines (THP1) were exposed to Co-Cr-Mo particles (derived from orthopaedic implants), as well as cobaltchromium-molybdenum (Co-Cr-Mo) and $\mathrm{Ti}$ ions $[14,15]$.

The surface roughness of $\mathrm{Co}-\mathrm{Cr}$ and titanium has been shown to influence the ion release and inflammatory response $[2, \underline{16}]$. In another in vitro study related to the present topic, it was shown that the rough surface created by anodized and fluorinated oxide with nanotubes of titanium grade 4, demonstrated reduced pro-inflammatory cytokine expression of IL-1 $\beta$, IL- 6 and TNF- $\alpha$, compared to the smoother surface of titanium grade 4 [17]. However, in another study no statistically significant differences were reported in cytokine expression (TNF- $\alpha$ and IL10) when comparing different modified surfaces of commercially pure titanium grade 3 [18].

Metal ions may act as initiators for osteolysis and aseptic loosening of an orthopaedic implant $[\underline{19}, \underline{20}]$. A previous in vitro study simulating the clinical situation of a dental implant connected to a supra-construction made of Co-Cr alloys demonstrated a lower total ion release when commercially pure titanium grade 4 (CpTi4) and $\mathrm{Co}-\mathrm{Cr}$ were simultaneously present, as compared to $\mathrm{Co}-\mathrm{Cr}$ solely [2]. Another in vitro study investigating implant supra-constructions concluded that the lower metal ion release from platform-switched supra constructions, compared to platform-matched, resulted in a decreased expression of pro-inflammatory cytokines (IL-6 and IL-8) and a reduced marginal bone loss for the platform-switched compared to platform-matched supra constructions [21-23]. However, the immune response to metal ions is a complex process not fully understood [19].

The aims of the present in vitro study were to examine cytokine release from human peripheral blood mononuclear cells exposed to cast, milled, laser melted, and presintered milled cobalt-chromium used in fixed prosthodontics compared to commercially pure titanium grade 4 and titanium alloy grade 23 with a known surface roughness.

The null hypothesis was that there are no differences in cytokine release regardless of material.

\section{MATERIAL AND METHODS}

This study involved five Co-Cr alloys manufactured with four different techniques: cast, milled, laser melted, and presintered milled (Table 1) [1]]: 
Table 1. Technical information of the specimens

\begin{tabular}{|c|c|c|}
\hline Manufacturing technique & Tradename & Composition (\%) \\
\hline Cast $^{1}$ & Wirobond $280^{\circledR}(\mathrm{W} 280)$ & $\mathrm{Co}=60.2 ; \mathrm{Cr}=25 ; \mathrm{Mo}=4.8 ; \mathrm{W}=6.2 ; \mathrm{Ga}=2.8 ; \mathrm{Si}<1 ; \mathrm{Mn}<1$ \\
\hline Cast $^{1}$ & $\operatorname{Remanium}^{\circledR}$ Star $(\mathrm{Rc})$ & $\mathrm{Co}=60.5 ; \mathrm{Cr}=28 ; \mathrm{Si}=1.5 ; \mathrm{W}=9 ; \mathrm{Mn}<1 ; \mathrm{N}<1 ; \mathrm{Nb}<1$ \\
\hline Milled $^{2}$ & Remanium $^{\circledR}$ Star MDII (Rm) & - \\
\hline Laser melted $^{3}$ & Remanium $^{\circledR}$ Star CL (Rlm) & - \\
\hline Presintered milled $^{4}$ & Zirkonzahn ${ }^{\circledR}$ Sintermetall $(\mathrm{Zz})$ & $\mathrm{Co}=62$ to $68 ; \mathrm{Cr}=26$ to $30 ; \mathrm{Mo}=5$ to $7 ; \mathrm{N}<0.5 ; \mathrm{C}<0.5$ \\
\hline Cold drawn & CpTi4 & $\mathrm{C}<0.01 ; \mathrm{N}<1 ; \mathrm{O}=0.33 ; \mathrm{Fe}=0.08 ; \mathrm{H}=0.01 ;$ Ti balance \\
\hline Drawn, annealed & Ti-6Al-4V ELI & $\begin{array}{l}\mathrm{Al}=5.96 \text { to } 6.05 ; \mathrm{V}=4.11 \text { to } 4.02 ; \mathrm{Fe}=0.14 \text { to } 0.17 ; \mathrm{C}=0.008 \text { to } \\
0.009 ; \mathrm{N}=0.004 \text { to } 0.005 ; \mathrm{O}=0 \text { to } 0.12 ; \mathrm{H}=0 \text { to } 0.0018 ; \text { Ti balance }\end{array}$ \\
\hline
\end{tabular}

${ }^{1}$ The cast specimens; W280 and Rc were cast by an experienced dental technician at the Dental Laboratory Technology in the Institute of Odontology, University of Gothenburg, Sahlgrenska Academy, Sweden, according to the manufacturer's recommendation.

${ }^{2}$ Processed by Kullberg Mikroteknik, Lycke, Sweden.

${ }^{3}$ Received prepared from the manufacturer.

${ }^{4}$ Final sintering at Säffle Dental AB, Säffle, Sweden. Processed by Kullberg Mikroteknik, Lycke, Sweden.

ELI $=$ extra-low interstitial.

- Cast Wirobond 280 ${ }^{\circledR}$ (W280) (BEGO; Bremen, Germany);

- Cast Remanium ${ }^{\circledR}$ Star (Rc) (Dentaurum GmbH \& Co. KG; Ispringen, Germany);

- Milled Remanium ${ }^{\circledR}$ Star MDII (Rm) (Dentaurum $\mathrm{GmbH} \& \mathrm{Co} . \mathrm{KG})$;

- Laser melted Remanium ${ }^{\circledR}$ Star CL (Rlm) (Dentaurum GmbH \& Co. KG);

- Presintered milled Zirkonzahn ${ }^{\circledR}$ Sintermetall (Zz) (Zirkonzahn S.R.L.; Gais, South Tyrol, Italy).

The laser melted $\mathrm{Co}-\mathrm{Cr}$ specimens were received prepared from the manufacturer. The milled $\mathrm{Co}-\mathrm{Cr}$ and titanium (CpTi4 and Ti-6Al-4V ELI) specimens were processed and finalized at a local milling center. As for the presintered milled $\mathrm{Co}-\mathrm{Cr}$ specimens, they were received in a presintered "soft" state and the finalizing milling and sintering process was performed at a dental laboratory. Only the cast specimens were prepared "in house" by an experienced dental technician. Commercially pure titanium grade 4 and Ti-6Al-4V ELI were included for comparison (Table 1) [1].

Five disc-shaped specimens, with a diameter of 8 $\mathrm{mm}$ and a thickness of $2 \mathrm{~mm}$ of each material, were ground on both flat sides with silicon carbide $(\mathrm{SiC})$ grinding paper 320 to 1200 grit size (Struers A/S; Ballerup, Denmark), using wet-grinding equipment (EXAKT Apparatebau GmbH \& Co. KG; Norderstedt, Germany). The post-grinding cleaning process included:

- 10 minutes in an ultrasonic bath at $60{ }^{\circ} \mathrm{C}$, in mixture of $1 \%$ Extran ${ }^{\circledR}$ AP 15 (Merck KGaA; Darmstadt, Germany), and $99 \%$ deionisized ultrapured water.

- Rinsing in deionized ultrapure water for 30 seconds.
- Followed by air drying and packing in a sterile bag (Wipak Oy; Helsinki, Finland).

\section{Cell culture}

Buffy coats were obtained from 10 anonymous healthy, volunteer blood donors at the Sahlgrenska University Hospital in Gothenburg, Sweden, between the $20^{\text {th }}$ of March and the $4^{\text {th }}$ of May, in 2018. Peripheral blood mononuclear cells (PBMCs) were isolated by Ficoll-Paque PLUS (GE Healthcare Bio-Sciences $\mathrm{AB}$; Uppsala, Sweden), washed twice in phosphatebuffered saline (PBS) and resuspended in Dulbecco's modified Eagle's medium + GlutaMAX-1 ${ }^{\mathrm{TM}}$ (Gibco, Life Technologies; Paisley, UK) supplemented with $5 \%$ heat inactivated human serum type AB (SigmaAldrich; St. Louis, Missouri, USA), penicillin (100 U/ $\mathrm{mL}$ - Sigma-Aldrich), and streptomycin $(100 \mathrm{lg} / \mathrm{mL}$ - Sigma-Aldrich). Cells were seeded at 2 x 106 cells per well with or without test material in 24-well plates and cultured at $37{ }^{\circ} \mathrm{C}$ in a humidified atmosphere with $5 \% \mathrm{CO}_{2}$. Supernatants were collected after 4, 24, and 72 hours of incubation and kept at minus $80{ }^{\circ} \mathrm{C}$ until further use.

\section{Cytokine analysis}

Cytokine concentrations in the culture supernatants were measured by Lumine ${ }^{\circledR}$ xMAP $^{\circledR}$ Technology (Luminex Crop.; Austin, Texas, USA) using the commercially available 21-plex and 27-plex screening panels of the Bio-Plex Pro ${ }^{\mathrm{TM}}$ Human Cytokine Assay (Bio-Rad Laboratories Inc.; Hemel Hempstead, UK) according to the instructions from the manufacturer. In brief, samples were thawed and centrifuged at $1000 \mathrm{x} \mathrm{g}$ for 10 minutes at $4{ }^{\circ} \mathrm{C}$ and added 
to a 96-well plate (Bio-Rad Laboratories Inc.,) prepared with color-coded magnetic beads conjugated with capture antibodies. After 45 min of incubation, followed by a washing procedure, biotinylated detection antibodies were added and allowed to bind for $30 \mathrm{~min}$. After another washing step, streptavidinconjugated phycoerythrin was added and, after a final washing procedure, quantitative data were acquired by running the samples through the BioPlex ${ }^{\circledR} 200$ instrument. All washing procedures were performed using the Bio-Plex Pro ${ }^{\mathrm{TM}}$ Wash Station (Bio-Rad Laboratories Inc.) and the program indicated in the assay protocol for each step. Analysis and calculations were made using the BioManager analysis software version 6.0 (Bio-Rad Laboratories Inc.) [12], with MountainsMap Premium 7.4.16 software (Digital Surf; Besancon, France).

\section{Surface roughness analysis}

Three disc-shaped specimens (size and cleaning procedure as described above) from each material were randomly selected and examined regarding surface topography with an optical interferometer (smartWLI-extended - GBS; Ilmenau, Germany). Five randomly selected regions/specimen were measured i.e. in total a mean number of 15 measurements per material. High-pass Gaussian filter $50 \times 50$ $\mu \mathrm{m}$ was utilized to separate roughness from errors of form and waviness [24]. According to previous recommendations, three surface parameters were calculated [24]:

- $\mathrm{S}_{\mathrm{a}}(\mu \mathrm{m})$ - the average height deviation of each point compared to the arithmetical mean of the surface.

- $\mathrm{S}_{\mathrm{ds}}\left(1 / \mu \mathrm{m}^{2}\right)$ - the density of the summits, i.e. number of summits per area.

- $\mathrm{S}_{\mathrm{dr}}(\%)$ - the developed interfacial area ratio; the percentage of the definition area's additional surface area contributed to the texture as compared to the planar unit definition area.

The surface evaluation was performed with MountainsMap Premium 7.4.16 software.

\section{Statistical analysis}

The statistical analysis for cytokine levels included Friedman's non-parametric test and Dunn's multiple correction test for post-hoc testing. The One Way ANOVA test was used for analysing surface properties and the Tukey test was applied for pairwise posthoc testing [25]. Parametric data were expressed as mean and standard deviation (SD). Data processing was performed using GraphPad Prism version 9.1.0 software (GrapdPad Software Inc.; La Jolla, California, USA) and SPSS version 27 (IBM Corp.; Armonk, New York, USA). The significance value level was set to $\mathrm{P}<0.05$.

\section{RESULTS \\ Cytokine analysis}

The results from the multiplex cytokine release test are visualized in the heat map in Figure 1. In general, four hours of incubation did not reveal any major differences between the materials. However, $\mathrm{Zz}$ demonstrated seemingly greater cytokine levels of IL-4 and IL-8 after $4 \mathrm{~h}$.

Overall, the milled, laser melted $\mathrm{Co}-\mathrm{Cr}$ and both titanium materials (CpTi4 and Ti-6Al-4V ELI) demonstrated lower levels of cytokine release (pro- and anti-inflammatory) compared to cast and presintered milled $\mathrm{Co}-\mathrm{Cr}$ alloys. The levels of cytokine release for the milled, laser melted $\mathrm{Co}-\mathrm{Cr}$ and titanium specimens, reached a similar level as the controls (cells without any specimen).

After one and three days, the pattern changed and higher cytokine levels were observed for the cast

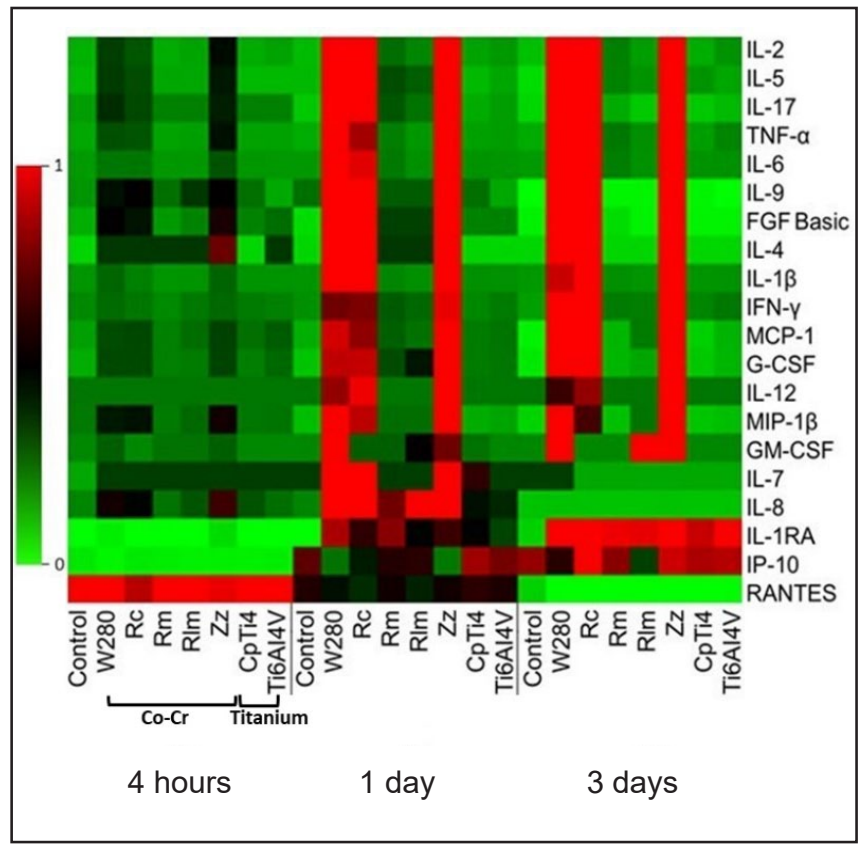

Figure 1. The columns from the heat map represent the specimen material (and control) and the rows represent the cytokine expression profiles from exposed (and non-exposed) peripheral blood mononuclear cells after three days of incubation.

The colour codes symbolize the mean levels of cytokine release from supernatants obtained from 10 anonymous healthy donors: red $=$ high; black $=$ intermediate; green $=$ low .

Co-Cr = cobalt-chromium; W280 = Wirobond $280^{\circledR} ; \mathrm{Rc}=$ Remanium $^{\circledR}$ Star; Rm $=$ Remanium $^{\circledR}$ Star MDII; Rlm $=$ Remanium $^{\circledR}$ Star CL; Zz = Zirkonzahn ${ }^{\circledR}$ Sintermetall; CpTi4 = commercially pure titanium grade 4 ; Ti-6Al-4V = titanium alloy grade 23 . 
$\mathrm{Co}-\mathrm{Cr}$ and presintered milled compared to the other $\mathrm{Co}-\mathrm{Cr}$ materials. Except for IL-1ra and IP10, lower cytokine level release could be observed from CpTi4 and Ti-6Al-4V ELI after three days compared to the $\mathrm{CoCr}$ materials. Thus, after both one and three days, the highest cytokine levels were observed for the cast $\mathrm{Co}-\mathrm{Cr}$ and presintered milled $\mathrm{Co}-\mathrm{Cr}$ specimens whereas the other $\mathrm{Co}-\mathrm{Cr}$ alloys, as well as CpTi4 and Ti-6Al-4V ELI, presented very low levels. The expression of pro-inflammatory cytokine levels from day three was selected for the statistical analysis. At the first registration (4 h), low cytokine levels were detected from all cells that were exposed to the materials tested, except for the expression level of RANTES that was upregulated, $\mathrm{P}>0.05$ (Figures 1, 2, 3). Low levels were observed for the controls of all materials, except for RANTES and IP-10 where the level decreased (for RANTES) and increased (for IP-10), but the differences were not statistically significant, $\mathrm{P}>0.05$. Statistically significant higher cytokine levels were observed for the following pro-inflammatory cytokines: IL-1 $\beta$, IL-6, IL-8, IL-17, IFN- $\gamma$, and TNF- $\alpha$ when exposed to the cast specimens compared to milled, laser melted, and both groups of titanium specimens, $\mathrm{P}<0.05$ (Figure 2). A higher value was also observed for the anti-inflammatory cytokine release of IL-4 when exposed to the cast (W280) as compared to milled and laser melted $\mathrm{Co}-\mathrm{Cr}$ specimens, $\mathrm{P}<$ 0.05 . Moreover, a higher expression level of antiinflammatory cytokines (IL-4, IL-10, IL-12, IL-ra) for both cast $\mathrm{Co}-\mathrm{Cr}$ specimens, compared to $\mathrm{CpTi}$, $\mathrm{P}<0.05$, was shown (Figure 3). Also, increased proinflammatory cytokine levels (IL-1 $\beta$, IL-17, IFN- $\gamma$ and $\mathrm{TNF}-\alpha$ ) and anti-inflammatory cytokines (IL-4, IL-12) were shown for the presintered milled Co-Cr specimens compared to the milled and laser melted Co-Cr specimens, $\mathrm{P}<0.05$. No difference in proand anti-inflammatory release was observed between the titanium specimens (CpTi4 and Ti-6Al-4V ELI), $\mathrm{P}>0.05$.

\section{Surface roughness analysis}

The results demonstrated extremely small statistically significant differences in surface roughness among the specimens. Range of difference: $\mathrm{S}_{\mathrm{a}}=0.02$ to $0.03 \mu \mathrm{m}$, $\mathrm{S}_{\mathrm{dr}}=0.9$ to $1.6 \%, \mathrm{~S}_{\mathrm{ds}}=0.03$ to $0.051 / \mu \mathrm{m}^{2}$. Slightly higher $\mathrm{S}_{\mathrm{a}}$ and $\mathrm{S}_{\mathrm{dr}}$ values for the milled and presintered milled $\mathrm{Co}-\mathrm{Cr}$ specimens and $\mathrm{CpTi}$, compared to the cast and laser melted $\mathrm{Co}-\mathrm{Cr}$ specimens, $\mathrm{P}<$ 0.05 . Commercially pure titanium grade 4 presented higher $\mathrm{S}_{\mathrm{dr}}$ values compared to Ti-6Al-4V ELI, $\mathrm{P}<$ 0.05. However, all Co-Cr specimens (except for the presintered) demonstrated higher $\mathrm{S}_{\mathrm{ds}}$ values compared to Ti-6Al-4V ELI, $\mathrm{P}<0.05$.

\section{DISCUSSION}

In summary, the results from the cytokine release test demonstrated that cast and presintered milled $\mathrm{Co}-\mathrm{Cr}$ specimens initiated higher cytokine levels compared to milled, laser melted $\mathrm{Co}-\mathrm{Cr}$ and titanium (CpTi4, Ti6A1-4V ELI) specimens.

As has been previously reported in the literature, the surface roughness may affect the inflammatory response to a material $[2,17,26]$. To avoid the possible impact of surface parameters in our results, we prepared the surfaces of the specimens according to a standardized protocol. Although the mean range difference in surface roughness was extremely small, a slightly rougher surface $\left(\mathrm{S}_{\mathrm{a}}, \mathrm{S}_{\mathrm{dr}}\right)$ was observed for the milled and presintered $\mathrm{Co}-\mathrm{Cr}$ specimens compared to cast and laser melted $\mathrm{Co}-\mathrm{Cr}$ specimens $(\mathrm{P}<0.05)$. In a previous study by our research group, it was demonstrated that cast $\mathrm{Co}-\mathrm{Cr}$ specimens showed higher ion release compared to the milled $\mathrm{Co}-\mathrm{Cr}$, although no statistically significant differences in surface roughness could be observed among them [2]. In another publication investigating surface roughness on the nanoscale, a rougher surface for the laser melted Co-Cr compared to cast, milled, and laser sintered $\mathrm{Co}-\mathrm{Cr}$ was demonstrated [27]. With respect to the limited literature regarding surface roughness parameters to $\mathrm{Co}-\mathrm{Cr}$ in relation to inflammatory response to monocytes, we concluded that the small differences in surface roughness among the materials were negligible [28, 29] (Table 2).

The results from the present study demonstrated that the cast $\mathrm{Co}-\mathrm{Cr}(\mathrm{Rc})$ specimen provoked a higher proinflammatory cytokine release as compared to the other alloys. Although small amounts of Mo (in W280 and $\mathrm{Zz}$ ), Si (in W280 and Zz) and Mn (in W280 and Rc) are added to improve the mechanical properties of $\mathrm{Co}-\mathrm{Cr}$ alloys, no general conclusion between included elements and inflammatory response could be drawn [30, $\underline{31}]$ (Table 1).

According to the previous literature, the cast $\mathrm{Co}-\mathrm{Cr}$ releases a higher amount of ions compared to laser melted $\mathrm{Co}-\mathrm{Cr}[\underline{2}, \underline{32-34}]$. It has been suggested that ion release provokes an up- and down- regulation of inflammatory regulators that may cause tissue destruction around dental or orthopaedic implants $[\underline{7}, \underline{21}, \underline{35}, \underline{36}]$. In a study investigating metal ions and cytokine expression in saliva from patients with oral lichen planus and dental prostheses, demonstrated a positive correlation between IL-1 $\beta$ and $\mathrm{Cr}$ ions [37]. 


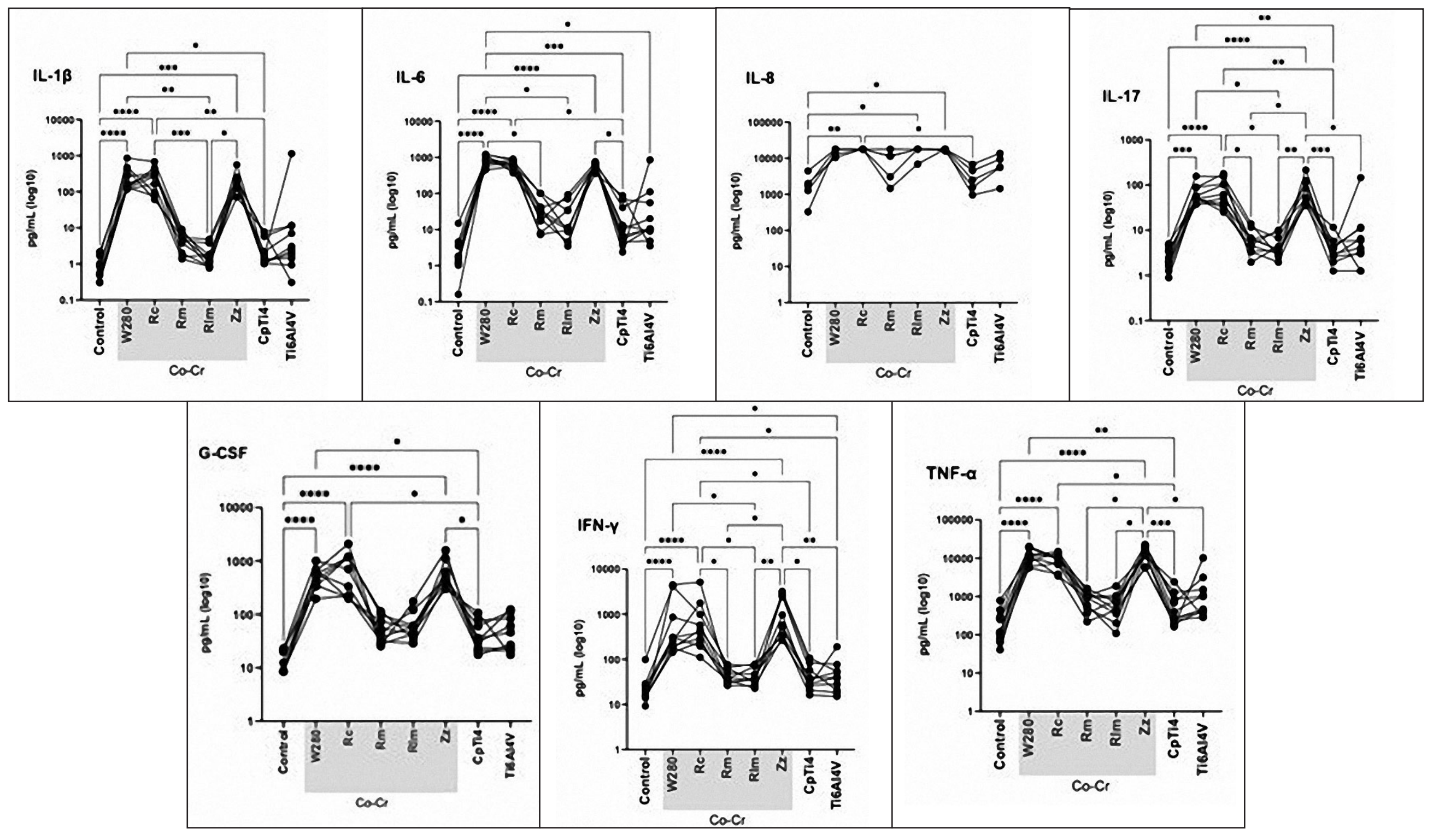

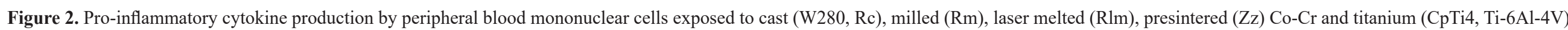

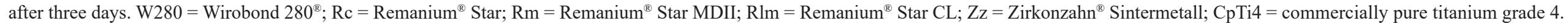




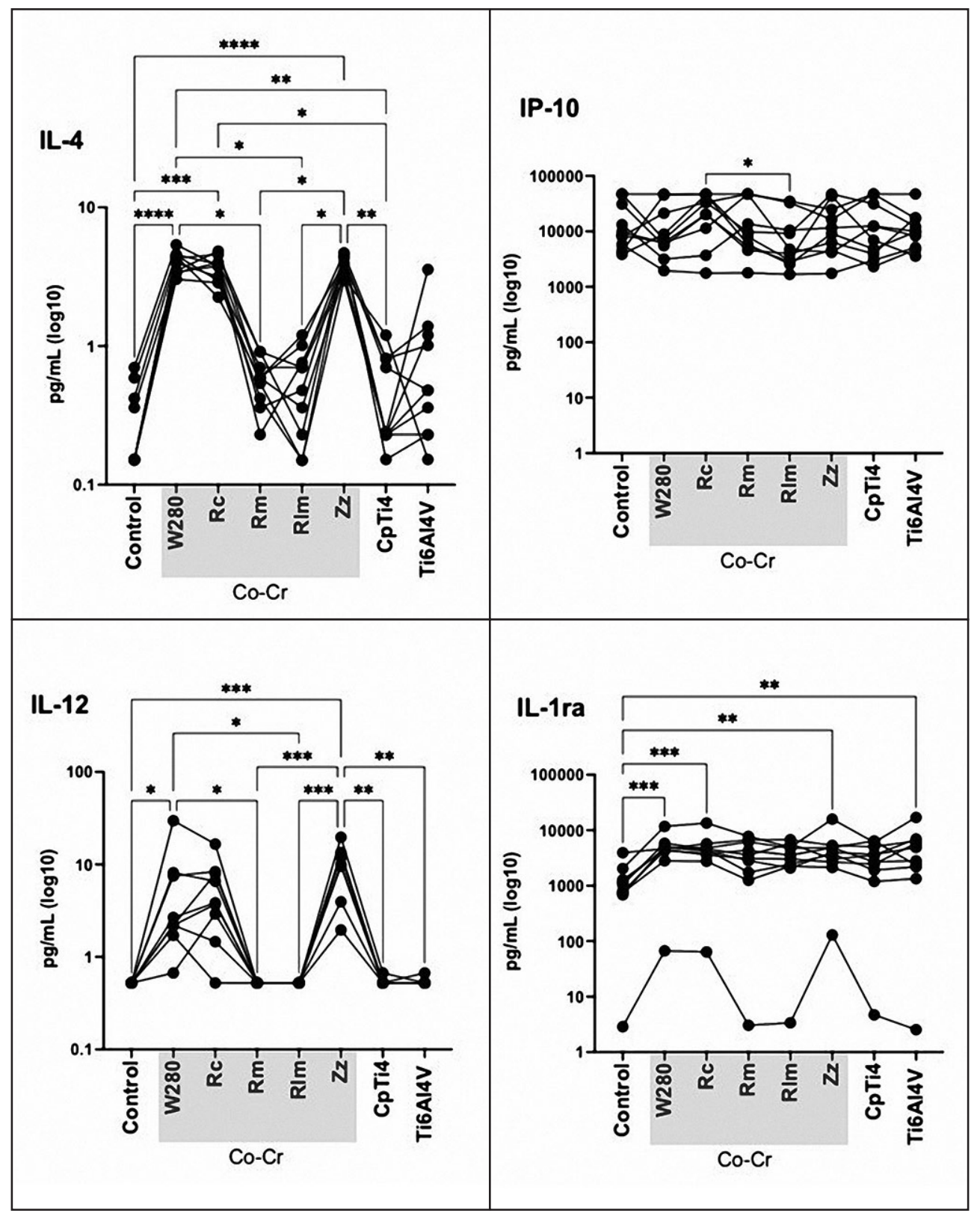

Figure 3. Anti-inflammatory cytokine production by peripheral blood mononuclear cells exposed to cast (W280, Rc), milled (Rm), laser melted (Rlm), presintered (Zz) Co-Cr and titanium (CpTi4, Ti-6Al-4V) after three days.

$\mathrm{Co}-\mathrm{Cr}=$ cobalt-chromium; W280 $=$ Wirobond $280^{\circledR} ; \mathrm{Rc}=$ Remanium $^{\circledR}$ Star; Rm $=$ Remanium ${ }^{\circledR}$ Star MDII; Rlm $=$ Remanium ${ }^{\circledR}$ Star CL; $\mathrm{Zz}=$ Zirkonzahn ${ }^{\circledR}$ Sintermetall; CpTi4 = commercially pure titanium grade 4; Ti-6Al-4V = titanium alloy grade 23.

Table 2. Results of surface analysis: $\mathrm{S}_{\mathrm{a}}, \mathrm{S}_{\mathrm{dr}}$ and $\mathrm{S}_{\mathrm{ds}}$

\begin{tabular}{|c|c|c|c|c|}
\hline & $S_{a}(\mu \mathrm{m})$ & $\mathrm{S}_{\mathrm{dr}}(\%)$ & $S_{d s}\left(1 / \mu m^{2}\right)$ \\
\hline & & Mean (SD) & Mean (SD) & Mean (SD) \\
\hline \multirow{5}{*}{ Cobalt-chromium } & Wirobond 280 ${ }^{\circledR}$ & $0.13(0.06)$ & $4.2(0.4)$ & $0.22(0.02)$ \\
\hline & Remanium ${ }^{\circledR}$ Star & $0.13(0.01)$ & $4.7(0.7)$ & $0.23(0.04)$ \\
\hline & Remanium $^{\circledR}$ Star MDII & $0.15(0.01)$ & $5.8(0.7)$ & $0.23(0.04)$ \\
\hline & Remanium ${ }^{\circledR}$ Star CL & $0.13(0.02)$ & $4.8(0.3)$ & $0.23(0.04)$ \\
\hline & Zirkonzahn ${ }^{\circledR}$ Sintermetall & $0.15(0.01)$ & $5.8(0.3)$ & $0.21(0.02)$ \\
\hline \multirow{2}{*}{ Titanium } & CpTi4 & $0.16(0.03)$ & $5.2(1.4)$ & $0.19(0.01)$ \\
\hline & Ti-6Al-4V & $0.14(0.01)$ & $3.8(0.3)$ & $0.21(0.01)$ \\
\hline
\end{tabular}

Mean range differences: $\mathrm{S}_{\mathrm{a}}=0.009$ to $0.01 \mu \mathrm{m}, \mathrm{S}_{\mathrm{dr}}=0.1$ to $0.7 \%, \mathrm{~S}_{\mathrm{ds}}=0.01$ to $0.02 / \mu \mathrm{m}^{2} ; \mathrm{P}<0.05$.

$\mathrm{SD}=$ standard deviation; $\mathrm{CpTi} 4=$ commercially pure titanium grade 4 ; Ti-6Al-4V = titanium alloy grade 23. 
The latter finding was confirmed in the present study, where the IL-1 $\beta$ cytokine was upregulated when cells were exposed to the cast and presintered Co$\mathrm{Cr}$ specimens. It should be noted that comparisons between these studies must be made with caution since ion release in in vivo conditions may be influenced by dietary intake, saliva composition, and the contents of prostheses' alloy that were not fully declared $[\underline{37}, \underline{38}]$.

In cases where the $\mathrm{Co}-\mathrm{Cr}$ supra-constructions are retained on the implant platform without an abutment, $\mathrm{Co}-\mathrm{Cr}$ is located deep in the sulcus and may interact and cause a reaction in the periimplant mucosa. Both tooth- and implant-supported supra-constructions manufactured by $\mathrm{Co}-\mathrm{Cr}$ are, to some extent, exposed to the oral cursive as well as the mucosa, and may release metal ions $[\underline{2}, \underline{21}, \underline{33}]$. This may induce an inflammatory response with the upregulation of cytokine mediators that may lead to bone destruction around an implant $[\underline{6}, 21]$. However, further research is needed to determine the role of the material and the specific cytokines in the mechanisms of inflammatory bone loss around dental implants as well as the interplay with bacteria $[\underline{6}, \underline{8}, \underline{39}, \underline{40}]$.

Within the limitations of the present study, the results showed a general upregulation of the pro- and antiinflammatory cytokines to the cast $\mathrm{Co}-\mathrm{Cr}$ compared to the laser melted. Both titanium materials (CpTi4 and Ti-6Al-4V ELI) demonstrated similar cytokine expression levels as the laser melted $\mathrm{Co}-\mathrm{Cr}$. The upregulation of cytokine level was not as prominent for the anti-inflammatory cytokines as for the proinflammatory cytokines (Figure 2 and 3 ). In the previous literature, the majority of the studies that have investigated the inflammatory response to implants are related to analyses of pro-inflammatory cytokines $[\underline{3}, \underline{6}, 10, \underline{14}, \underline{15}, 17, \underline{20}, \underline{21}, 26, \underline{37}, \underline{41}, \underline{42}] . \quad$ The present study classifies IL-4 as an anti-inflammatory cytokine that may contribute to inhibit bone resorption $[\underline{8}, \underline{36}, \underline{43}]$. In other studies IL-4 has been classified as a pro-inflammatory or adaptive immunity cytokine $[\underline{11}, \underline{12}, \underline{26}, \underline{44}]$. It has been proposed that IL-4 should be defined as a pleiotropic (polyfunctional) cytokine that acts both as an inhibitor and enhancer for the expression of mediators to osteoblasts, osteoclasts, fibroblasts, and inflammatory cells $[\underline{8}, \underline{45}]$. The multiple roles of specific cytokines display the variety and complexity of ways to understand the inflammatory response.

Furthermore, an increased ion release from cast Co-Cr compared to the laser melted, that has been demonstrated in an earlier publication, may also contribute to the upregulation of cytokines [2]. The microstructure of a material is another factor that may affect the ion release and thereby the inflammatory response [32]. Studies have demonstrated that laser melted Co-Cr specimens showed smaller grain size and a more homogeneous and dense structure compared to the cast $\mathrm{Co}-\mathrm{Cr}$ specimens [46-53]. It has been demonstrated that a rapid cooling and strong temperature gradient in the manufacturing process of laser melted $\mathrm{Co}-\mathrm{Cr}$ resulted in a more corrosionresistant microstructure as compared to the procedures of the casting technique [32]. It may be suggested that microstructural differences between laser melted and cast $\mathrm{Co}-\mathrm{Cr}$ alloys regarding (a) the non-presence of segregation of $\mathrm{Co}$ and $\mathrm{Cr}$ in laser melted $\mathrm{Co}-\mathrm{Cr}$ alloys, and (b) the type of secondary phases, results in a decreased ion release from laser melted $\mathrm{Co}-\mathrm{Cr}$ alloys compared to cast $\mathrm{Co}-\mathrm{Cr}$ alloys $[\underline{2}, \underline{48}, \underline{54}]$.

In order to further understand the microstructural factors that may contribute to differences in ion release and subsequent cytokine levels between the materials, more research is needed.

Despite the limitations of the present study, the significance of basic research is that it contributes to an increased understanding of the potential cellular effects of metal-based dental prostheses.

In summary, it can be concluded that an upregulated inflammatory response was mainly observed to the cast $\mathrm{Co}-\mathrm{Cr}$ alloys. Laser melted $\mathrm{Co}-\mathrm{Cr}$ and titanium (CpTi4 and Ti-6Al-4V ELI) demonstrated a similar inflammatory response, but one that was lower compared to cast $\mathrm{Co}-\mathrm{Cr}$.

The null hypothesis was rejected since the cytokine release among the cells exposed to the different materials differed, $\mathrm{P}<0.05$.

\section{CONCLUSIONS}

Within the limitations of the present study, it may be suggested that cast and presintered milled cobaltchromium alloys provoke a stronger inflammatory response compared to milled and laser melted cobaltchromium alloys and titanium materials.

\section{ACKNOWLEDGMENTS AND DISCLOSURE STATEMENTS}

The authors wish to thank: Dentaurum GmbH \& Co. KG (Ispringen, Germany) for its contribution of material and specimens; engineer Fredrik Kullberg at Kullbergs Mikroteknik, Lycke, Sweden and dental technician Jetmir Kazaat, Säffle Dental, Säffle, Sweden for their help in specimen preparation; dental technician Pia Karlsson, Göteborg, Sweden for her 
help with specimen preparation.

Declarations of interest: None.

Funding: This work was supported by Futurum-the Academy for Health and Care, Region Jönköping
County, Jönköping, Sweden, Swedish Dental Society, Stockholm, Sweden, Sylvan Foundation, Göteborg, Sweden and Folktandvården Sörmland $\mathrm{AB}$, Nyköping, Sweden.

\section{REFERENCES}

1. Kassapidou M, Franke Stenport V, Hjalmarsson L, Johansson CB. Cobalt-chromium alloys in fixed prosthodontics in Sweden. Acta Biomater Odontol Scand. 2017 Aug 11;3(1):53-62. [Medline: 29242813] [PMC free article: 5724798] [doi: 10.1080/23337931.2017.1360776]

2. Kassapidou M, Hjalmarsson L, Johansson CB, Hammarström Johansson P, Morisbak E, Wennerberg A, Franke Stenport V. Cobalt-chromium alloys fabricated with four different techniques: Ion release, toxicity of released elements and surface roughness. Dent Mater. 2020 Nov;36(11):e352-e363. [Medline: 32943232] [doi: 10.1016/j.dental.2020.08.012]

3. Schmalz G, Garhammer P. Biological interactions of dental cast alloys with oral tissues. Dent Mater. 2002 Jul;18(5): 396-406. [Medline: 12175579] [doi: 10.1016/s0109-5641(01)00063-x]

4. Anusavice KJ, Phillips RW, Shen C, Rawls HR. Dental casting alloys and metal joining. In: Anusavice KJ, Phillips RW, Shen C, Rawls HR, editors. Phillips' science of dental materials, 12th ed. St. Louis, Mo.: Elsevier/Saunders; 2013. p. 116-7.

5. Albrektsson T, Dahlin C, Jemt T, Sennerby L, Turri A, Wennerberg A. Is marginal bone loss around oral implants the result of a provoked foreign body reaction? Clin Implant Dent Relat Res. 2014 Apr;16(2):155-65. [Medline: 24004092] [doi: 10.1111/cid.12142]

6. Pettersson M, Kelk P, Belibasakis GN, Bylund D, Molin Thorén M, Johansson A. Titanium ions form particles that activate and execute interleukin-1 $\beta$ release from lipopolysaccharide-primed macrophages. J Periodontal Res. 2017 Feb;52(1): 21-32[Medline: 26987886] [PMC free article: 5297875] [doi: 10.1111/jre.12364]

7. Czarnek K, Terpiłowska S, Siwicki AK. Selected aspects of the action of cobalt ions in the human body. Cent Eur J Immunol. 2015;40(2):236-42. [Medline: 26557039] [PMC free article: 4637398]

8. Souza PP, Lerner UH. The role of cytokines in inflammatory bone loss. Immunol Invest. 2013;42(7):555-622. [Medline: 24004059] [doi: 10.3109/08820139.2013.822766]

9. Ratner BD. Introduction: The Body Fights Back - Degradation of Materials in the Biological Environment. In: Ratner BD, Hoffman AS, Schoen FJ, Lemons JE, editors. Biomaterials Science (Third Edition): An Introduction to Materials in Medicine. Amsterdam: Elsevier Academic Press; 2013. p. 520. [doi: 10.1016/B978-0-08-087780-8.00059-0]

10. Schmalz G, Schuster U, Schweikl H. Influence of metals on IL-6 release in vitro. Biomaterials. 1998 Sep;19(18):1689-94. [Medline: 9840004] [doi: 10.1016/S0142-9612(98)00075-1]

11. Cavaillon JM. Pro- versus anti-inflammatory cytokines: myth or reality. Cell Mol Biol (Noisy-le-grand). 2001 Jun; 47(4):695-702. [Medline: 11502077]

12. Pro-Inflammatory Cytokines Overview. Thermo Fisher Scientific. 2021. [cited 2021 nov 25]. [URL: https:// www.thermofisher.com/se/en/home/life-science/cell-analysis/cell-analysis-learning-center/immunology-at-work/ proinflammatory-cytokines-overview.html]

13. Turner MD, Nedjai B, Hurst T, Pennington DJ. Cytokines and chemokines: At the crossroads of cell signalling and inflammatory disease. Biochim Biophys Acta. 2014 Nov;1843(11):2563-2582. [Medline: 24892271] [doi: 10.1016/j.bbamcr.2014.05.014]

14. Caicedo MS, Pennekamp PH, McAllister K, Jacobs JJ, Hallab NJ. Soluble ions more than particulate cobalt-alloy implant debris induce monocyte costimulatory molecule expression and release of proinflammatory cytokines critical to metal-induced lymphocyte reactivity. J Biomed Mater Res A. 2010 Jun 15;93(4):1312-21. [Medline: 19844976] [doi: $10.1002 / \mathrm{jbm} . \mathrm{a} .32627$ ]

15. de Molon RS, Rossa C Jr, Thurlings RM, Cirelli JA, Koenders MI. Linkage of Periodontitis and Rheumatoid Arthritis: Current Evidence and Potential Biological Interactions. Int J Mol Sci. 2019 Sep 13;20(18):4541. [Medline: 31540277] [PMC free article: 6769683 ] [doi: 10.3390/ijms20184541]

16. Wennerberg A, Albrektsson T. Effects of titanium surface topography on bone integration: a systematic review. Clin Oral Implants Res. 2009 Sep;20 Suppl 4:172-84. [Medline: 19663964] [doi: 10.1111/j.1600-0501.2009.01775.x]

17. Östberg AK, Dahlgren U, Sul YT, Johansson CB. Inflammatory cytokine release is affected by surface morphology and chemistry of titanium implants. J Mater Sci Mater Med. 2015 Apr;26(4):155. [Medline: 25779512] [doi: 10.1007/s10856-015-5486-3]

18. Göransson A, Gretzer C, Johansson A, Sul YT, Wennerberg A. Inflammatory response to a titanium surface with potential bioactive properties: an in vitro study. Clin Implant Dent Relat Res. 2006;8(4):210-7. [Medline: 17100746] [doi: 10.1111/j.1708-8208.2006.00021.x]

19. Magone K, Luckenbill D, Goswami T. Metal ions as inflammatory initiators of osteolysis. Arch Orthop Trauma Surg. 2015 May;135(5):683-95. [Medline: 25795427] [doi: 10.1007/s00402-015-2196-8] 
20. Jonitz-Heincke A, Sellin ML, Seyfarth A, Peters K, Mueller-Hilke B, Fiedler T, Bader R, Klinder A. Analysis of Cellular Activity Short-Term Exposure to Cobalt and Chromium Ions in Mature Human Osteoblasts. Materials (Basel). 2019 Aug 28;12(17):2771. [Medline: 31466377] [PMC free article: 6747798] [doi: 10.3390/ma12172771]

21. Alrabeah GO, Brett P, Knowles JC, Petridis H. The effect of metal ions released from different dental implantabutment couples on osteoblast function and secretion of bone resorbing mediators. J Dent. 2017 Nov;66:91-101. [Medline: 28800964] [doi: 10.1016/j.jdent.2017.08.002]

22. Lazzara RJ, Porter SS. Platform switching: a new concept in implant dentistry for controlling postrestorative crestal bone levels. Int J Periodontics Restorative Dent. 2006 Feb;26(1):9-17. [Medline: 16515092]

23. Canullo L, Fedele GR, Iannello G, Jepsen S. Platform switching and marginal bone-level alterations: the results of a randomized-controlled trial. Clin Oral Implants Res. 2010 Jan;21(1):115-21. [Medline: 20070752] [doi: 10.1111/j.1600-0501.2009.01867.x]

24. Wennerberg A, Albrektsson T. Suggested guidelines for the topographic evaluation of implant surfaces. Int J Oral Maxillofac Implants. 2000 May-Jun;15(3):331-44. [Medline: 10874798]

25. Lee S, Lee DK. What is the proper way to apply the multiple comparison test? Korean J Anesthesiol. 2018 Oct;71(5):353360. doi: 10.4097/kja.d.18.00242. Epub 2018 Aug 28. Erratum in: Korean J Anesthesiol. 2020 Dec;73(6):572. [Medline: 30157585] [PMC free article: 6193594] [doi: 10.4097/kja.d.18.00242]

26. Barkarmo S, Östberg AK, Johansson CB, Franco-Tabares S, Johansson PH, Dahlgren U, Stenport V. Inflammatory cytokine release from human peripheral blood mononuclear cells exposed to polyetheretherketone and titanium-6 aluminum-4 vanadium in vitro. J Biomater Appl. 2018 Aug;33(2):245-258. [Medline: 30001662] [doi: 10.1177/0885328218786005]

27. Porojan S, Bîrdeanu M, Savencu C, Porojan L. Structural and morphological approach of Co-Cr dental alloys processed by alternative manufacturing technologies. J Phys. Conference Series. 2017;885:012005. [doi: 10.1088/1742-6596/885/1/012005]

28. Baranov MV, Kumar M, Sacanna S, Thutupalli S, van den Bogaart G. Modulation of Immune Responses by Particle Size and Shape. Front Immunol. 2021 Feb 12;11:607945. [Medline: 33679696] [PMC free article: 7927956] [doi: 10.3389/fimmu.2020.607945]

29. Caicedo MS, Samelko L, McAllister K, Jacobs JJ, Hallab NJ. Increasing both CoCrMo-alloy particle size and surface irregularity induces increased macrophage inflammasome activation in vitro potentially through lysosomal destabilization mechanisms. J Orthop Res. 2013 Oct;31(10):1633-42. [Medline: 23794526] [PMC free article: 4028039] [doi: 10.1002/jor.22411]

30. Karpuschewski B, Pieper HJ, Krause M, Döring J. CoCr Is Not the Same: CoCr-Blanks for Dental Machining. In: Schuh G, Neugebauer R, Uhlmann E, editors. Future Trends in Production Engineering. Berlin/Heidelberg: Springer-Verlag; 2013. p. 261-74. [doi: 10.1007/978-3-642-24491-9_26]

31. Konieczny B, Szczesio-Wlodarczyk A, Sokolowski J, Bociong K. Challenges of Co-Cr Alloy Additive Manufacturing Methods in Dentistry-The Current State of Knowledge (Systematic Review). Materials (Basel). 2020 Aug 10;13(16): 3524. [Medline: 32785055] [PMC free article: 7475880] [doi: 10.3390/ma13163524]

32. Hedberg YS, Qian B, Shen Z, Virtanen S, Wallinder IO. In vitro biocompatibility of CoCrMo dental alloys fabricated by selective laser melting. Dent Mater. 2014 May;30(5):525-34. [Medline: 24598762] [doi: 10.1016/j.dental.2014.02.008]

33. Lucchetti MC, Fratto G, Valeriani F, De Vittori E, Giampaoli S, Papetti P, Romano Spica V, Manzon L. Cobalt-chromium alloys in dentistry: An evaluation of metal ion release. J Prosthet Dent. 2015 Oct;114(4):602-8. [Medline: 25979449] [doi: 10.1016/j.prosdent.2015.03.002]

34. Puskar T, Jevremovic D, Williams RJ, Eggbeer D, Vukelic D, Budak I. A Comparative Analysis of the Corrosive Effect of Artificial Saliva of Variable pH on DMLS and Cast Co-Cr-Mo Dental Alloy. Materials (Basel). 2014 Sep 11;7(9): 6486-6501. [Medline: 28788197] [PMC free article: 5456152] [doi: 10.3390/ma7096486]

35. Catelas I, Petit A, Vali H, Fragiskatos C, Meilleur R, Zukor DJ, Antoniou J, Huk OL. Quantitative analysis of macrophage apoptosis vs. necrosis induced by cobalt and chromium ions in vitro. Biomaterials. 2005 May;26(15):2441-53. [Medline: 15585247] [doi: 10.1016/j.biomaterials.2004.08.004]

36. Duarte PM, Serrão CR, Miranda TS, Zanatta LC, Bastos MF, Faveri M, Figueiredo LC, Feres M. Could cytokine levels in the peri-implant crevicular fluid be used to distinguish between healthy implants and implants with peri-implantitis? A systematic review. J Periodontal Res. 2016 Dec;51(6):689-698. [Medline: 26774043] [doi: 10.1111/jre.12354]

37. Ju HM, Yu SN, Ahn YW, Ok SM, Ahn SC, Jeong SH. Correlation between Metal Ions and Cytokines in the Saliva of Patients with Oral Lichenoid Lesions. Yonsei Med J. 2021 Aug;62(8):767-775. [Medline: 34296555] [PMC free article: $\underline{\text { 8298875] }}$ [doi: $\underline{10.3349 / y m j .2021 .62 .8 .767]}$

38. El Sawy AA, Shaarawy MA. Evaluation of metal ion release from Ti6Al4V and Co-Cr-Mo casting alloys: in vivo and in vitro study. J Prosthodont. 2014 Feb;23(2):89-97. [Medline: 23755902] [doi: 10.1111/jopr.12067]

39. Lu C, Zheng Y, Zhong Q. Corrosion of dental alloys in artificial saliva with Streptococcus mutans. PLoS One. 2017 Mar 28;12(3):e0174440. [Medline: 28350880] [PMC free article: 5370117] [doi: 10.1371/journal.pone.0174440]

40. Kozmos M, Virant P, Rojko F, Abram A, Rudolf R, Raspor P, Zore A, Bohinc K. Bacterial Adhesion of Streptococcus mutans to Dental Material Surfaces. Molecules. 2021 Feb 21;26(4):1152. [Medline: 33670043] [PMC free article: 7926644] [doi: 10.3390/molecules26041152] 
41. Alizadehgharib S, Östberg AK, Dahlgren U. Triethylene glycol dimethacrylate: adjuvant properties and effect on cytokine production. Acta Biomater Odontol Scand. 2017 Dec 5;4(1):1-9. [Medline: 29230430] [PMC free article: 5717717] [doi: 10.1080/23337931.2017.1409075]

42. Barwacz CA, Brogden KA, Stanford CM, Dawson DV, Recker EN, Blanchette D. Comparison of pro-inflammatory cytokines and bone metabolism mediators around titanium and zirconia dental implant abutments following a minimum of 6 months of clinical function. Clin Oral Implants Res. 2015 Apr;26(4):e35-e41. [Medline: 24417614] [PMC free article: 4096610] [doi: 10.1111/clr.12326]

43. Zhou X, Fragala MS, McElhaney JE, Kuchel GA. Conceptual and methodological issues relevant to cytokine and inflammatory marker measurements in clinical research. Curr Opin Clin Nutr Metab Care. 2010 Sep;13(5):541-7. [Medline: 20657280] [PMC free article: 2955626] [doi: 10.1097/MCO.0b013e32833cf3bc]

44. Christiansen RJ, Münch HJ, Bonefeld CM, Thyssen JP, Sloth JJ, Geisler C, Søballe K, Jellesen MS, Jakobsen SS. Cytokine Profile in Patients with Aseptic Loosening of Total Hip Replacements and Its Relation to Metal Release and Metal Allergy. J Clin Med. 2019 Aug 20;8(8):1259. [Medline: 31434199] [PMC free article: 6723430] [doi: 10.3390/jcm8081259]

45. Keegan AD, Leonard WJ, Zhu J. Recent advances in understanding the role of IL-4 signaling. Fac Rev. 2021 Sep 7;10:71. [Medline: 34557875 ] [PMC free article: $\underline{\text { 8442009] [doi: 10.12703/r/10-71] }}$

46. Kim HR, Jang SH, Kim YK, Son JS, Min BK, Kim KH, Kwon TY. Microstructures and Mechanical Properties of Co-Cr Dental Alloys Fabricated by Three CAD/CAM-Based Processing Techniques. Materials (Basel). 2016 Jul 20;9(7):596. [Medline: 28773718] [PMC free article: 5456947] [doi: 10.3390/ma9070596]

47. Al Jabbari YS, Barmpagadaki X, Psarris I, Zinelis S. Microstructural, mechanical, ionic release and tarnish resistance characterization of porcelain fused to metal $\mathrm{Co}-\mathrm{Cr}$ alloys manufactured via casting and three different $\mathrm{CAD} / \mathrm{CAM}$ techniques. J Prosthodont Res. 2019 Apr;63(2):150-156. [Medline: 30642700] [doi: 10.1016/j.jpor.2018.10.008]

48. Zhou Y, Li N, Yan J, Zeng Q. Comparative analysis of the microstructures and mechanical properties of Co-Cr dental alloys fabricated by different methods. J Prosthet Dent. 2018 Oct;120(4):617-623. [Medline: 29627206] [doi: 10.1016/j.prosdent.2017.11.015]

49. Koutsoukis T, Zinelis S, Eliades G, Al-Wazzan K, Rifaiy MA, Al Jabbari YS. Selective Laser Melting Technique of CoCr Dental Alloys: A Review of Structure and Properties and Comparative Analysis with Other Available Techniques. J Prosthodont. 2015 Jun;24(4):303-12. [Medline: 26129918] [doi: 10.1111/jopr.12268]

50. Alageel O, Abdallah MN, Alsheghri A, Song J, Caron E, Tamimi F. Removable partial denture alloys processed by laser-sintering technique. J Biomed Mater Res B Appl Biomater. 2018 Apr;106(3):1174-1185. [Medline: 28561993] [doi: 10.1002/jbm.b.33929]

51. Li KC, Prior DJ, Waddell JN, Swain MV. Comparison of the microstructure and phase stability of as-cast, CAD/CAM and powder metallurgy manufactured Co-Cr dental alloys. Dent Mater. 2015 Dec;31(12):e306-15. [Medline: 26597769] [doi: 10.1016/j.dental.2015.10.010]

52. Lee DH, Hanawa T, Jang SH, Lee HJ, Hong MH, Min BK, Kwon TY. Effect of Post-Sintering Conditions on the Mechanical Properties of a New Co-Cr Alloy Produced by New Subtractive Manufacturing. J Nanosci Nanotechnol. 2019 Apr 1;19(4):2395-2398. [Medline: 30487007] [doi: 10.1166/jnn.2019.15984]

53. Hong MH, Lee DH, Hanawa T, Kwon TY. Comparison of microstructures and mechanical properties of 3 cobaltchromium alloys fabricated with soft metal milling technology. J Prosthet Dent. 2020 Dec 7:S0022-3913(20)30622-3. [Medline: 33303192] [doi: 10.1016/j.prosdent.2020.07.037]

54. Dong X, Li N, Zhou Y, Peng H, Qu Y, Sun Q, Shi H, Li R, Xu S, Yan J. Grain boundary character and stress corrosion cracking behavior of Co-Cr alloy fabricated by selective laser melting. Journal of Materials Science \& Technology. 2021 May;93:244-53. [doi: 10.1016/j.jmst.2021.03.063]

\section{To cite this article:}

Kassapidou M, Stenport VF, Johansson CB, Östberg AK, Hammarström Johansson P, Hjalmarsson L.

Inflammatory Response to Cobalt-Chromium Alloys Fabricated With Different Techniques

J Oral Maxillofac Res 2021;12(4):e3

URL: http://www.ejomr.org/JOMR/archives/2021/4/e3/v12n4e3.pdf

doi: $10.5037 /$ jomr.2021.12403

Copyright (C) Kassapidou M, Stenport VF, Johansson CB, Östberg AK, Hammarström Johansson P, Hjalmarsson L. Published in the JOURNAL OF ORAL \& MAXILLOFACIAL RESEARCH (http://www.ejomr.org), 31 December 2021.

This is an open-access article, first published in the JOURNAL OF ORAL \& MAXILLOFACIAL RESEARCH, distributed under the terms of the Creative Commons Attribution-Noncommercial-No Derivative Works 3.0 Unported License, which permits unrestricted non-commercial use, distribution, and reproduction in any medium, provided the original work and is properly cited. The copyright, license information and link to the original publication on (http://www.ejomr.org) must be included. 